(c) American Dairy Science Association, 2002.

\title{
Isolation and Partial Characterization of CD36 from Skim Milk ${ }^{1}$
}

\author{
C. P. Wilcox, V. G. Janolino, and H. E. Swaisgood \\ Department of Food Science, North Carolina State University, Raleigh 27695-7624
}

\begin{abstract}
CD36, a common milk fat globule membrane glycoprotein, was isolated from skim milk by methods similar to those previously utilized for the isolation of sulfhydryl oxidase. Two separate methods that were employed gave similar purity as observed by electrophoresis. The first was based on differential centrifugation and size-exclusion chromatography, whereas the second combined ultrafiltration and affinity chromatography. After significant purification, the protein was identified by Western blotting and sequence analysis. Deglycosylation decreased the apparent molecular mass from approximately 85 to 57 $\mathrm{kDa}$. These results suggested tissue-specific glycosylation. The purified fractions also exhibited low levels of sulfhydryl oxidase activity, the significance of which will require further study.
\end{abstract}

(Key words: CD36, milk fat globule membrane, skim milk, sulfhydryl oxidase)

Abbreviation key: EDC = 1-ethyl-3- (diethylaminopropyl)carbodiimide, HABA = 2- (4'-Hydroxybenzeneazo) benzoic acid, LDL = low-density lipoprotein, $\mathbf{M F G M}=$ milk fat globule membrane, $\mathbf{S O X}=$ sulfhydryl oxidase.

\section{INTRODUCTION}

Many of the proteins found in milk fat globule membranes (MFGM) have been isolated and characterized in an attempt to determine their biological functions (Mather et al., 1980; Greenwalt, 1993; Sato, et al., 1993). One such protein, which has been studied most extensively over the last $10 \mathrm{yr}$, is CD36 (Tandon et al., 1989). CD36 has also been observed in platelet fetal erythrocytes and mammary epithelial cells (Greenwalt

Received December 5, 2001.

Accepted January 25, 2002.

Corresponding author: H. E. Swaisgood; e-mail: harold_ swaisgood@ncsu.edu.

${ }^{1}$ Paper No. FSR 02-7 of the Journal Series of the Department of Food Science, North Carolina State University, Raleigh, NC 276957624. The use of trade names in this publication implies neither endorsement by the North Carolina Agricultural Research Service of products named nor criticism of similar ones not mentioned. and Mather, 1985). This glycoprotein has a molecular mass ranging from 75 to $88 \mathrm{kDa}$ depending on its source (Greenwalt et al., 1990a; Berglund et al., 1996). It has been speculated and, in some cases, demonstrated that these differences in mass are the result of varying degrees of glycosylation in specific tissues (Greenwalt et al., 1990b). Ligands for CD36 include oxidized low-density lipoproteihn (LDL [Endenmann et al., 1993]), fatty acid binding protein (Spitsberg et al., 1995), and thrombospondin (Silverstein et al., 1992). It has thus been suggested that the protein acts as a scavenger receptor for LDL and is a cell-adhesion molecule. However, the specific biological function of CD36 is yet unknown. Therefore, it is of interest to report that a form of CD36, distinct from that found in MFGM, was isolated from skim milk membrane vesicles. In this communication, we report the isolation of CD36 from skim milk using two separate methods.

\section{MATERIALS AND METHODS}

\section{Materials}

Chymosin was obtained as Chymax from Pfizer (Terre Haute, IN). Ultrafiltration membranes and apparatus were obtained from Millipore (Bedford, MA). Controlled-pore glass was purchased from CPG Incorporated (Terre Haute, IN). The HPDP biotinylation reagent, 2-(4'-Hydroxybenzeneazo)benzoic acid (HABA), avidin, and the bicinchoninic acid protein reagents were purchased from Pierce Chemical Co. (Rockford, IL). Electrophoresis and Western blotting materials were obtained from Amersham (Piscataway, NJ). All other chemicals were purchased from Sigma (St. Louis, MO).

\section{Methods}

Whey fractionation. One $\mathrm{L}$ of fresh, raw milk was obtained from the morning milking at the NCSU dairy farm. The milk was skimmed by centrifuging at 4,080 $\times g$ for 30 min at $30^{\circ} \mathrm{C}$. The casein was coagulated with 4 units of chymosin/100 ml of skim milk and removed by centrifuging at $16,300 \times g$ for $45 \mathrm{~min}$ at $30^{\circ} \mathrm{C}$.

Differential centrifugation/size-exclusion. Ammonium sulfate was added to the whey to $50 \%$ satura- 
tion and allowed to stand overnight at $4{ }^{\circ} \mathrm{C}$. The solution was then centrifuged at $16,300 \times g$ for $60 \mathrm{~min}$ at $4^{\circ} \mathrm{C}$. The precipitate was dissolved in phosphate buffer to give a protein concentration of $3 \%$ (Fraction $\mathrm{C}$ ). The sample was subsequently dialyzed and diluted to $0.15 \%$ protein. This sample stood overnight at $4^{\circ} \mathrm{C}$, after which it was centrifuged at $2000 \times \mathrm{g}$ for $30 \mathrm{~min}$. The supernatant was concentrated once again to $3 \%$ protein (Fraction E). The preceding protocol was based on the work of Janolino and Swaisgood (1975). A 50$\mu \mathrm{l}$ sample was applied to a Superose 12 size-exclusion column at a flow rate of $0.5 \mathrm{ml} / \mathrm{min}$, using $50 \mathrm{mM}$ phosphate buffer as the continuous phase. Fractions of the void volume were collected at 30-s intervals.

Ultrafiltration. Four liters of raw, skim milk was obtained from the NCSU dairy. Chymosin treatment was performed as described previously, followed by filtration through cheesecloth and paper. Ultrafiltration/diafiltration (100 kDa exclusion, spiral-wound membrane) of $3 \mathrm{~L}$ of the resulting whey fraction with $50 \mathrm{~m} M$ phosphate, $\mathrm{pH} 7.0$, gave $300 \mathrm{ml}$ of concentrated, dialyzed sample. Subsequent steps were based on the work of Janolino and Swaisgood (1993). Samples were applied (100 $\mathrm{ml}$ for each trial) to a CPG-3000 permeation column at a flow rate of $10 \mathrm{ml} / \mathrm{min}$. The void volume material $(250 \mathrm{ml})$ containing the skim milk membrane vesicles was then solubilized using $1 \%$ of the nonionic detergent polyoxyethylene-9-lauryl ether. Insoluble material was removed by centrifugation at 100,000 $\times$ g for 45 min (Sliwkowski et al., 1982).

Biotinylation. The solubilized vesicles were concentrated 10-fold and biotinylated using a sulfhydrylreactive reagent ( $4 \mathrm{~m} M$ HPDP-Biotin) for $2 \mathrm{~h}$ at room temperature. Progression of the reaction was monitored at $343 \mathrm{~nm}$, following the release of pyridine2-thione.

Avidin affinity chromatography. An avidinbased affinity matrix was prepared from cleaned controlled-pore glass beads by derivatization using $10 \%$ of a solution of 3-aminopropyltriethoxysilane for $3 \mathrm{~h}$ at $70^{\circ} \mathrm{C}$. The aminopropyl beads were treated with $1 \%$ triethylamine in acetone, containing $10 \%$ succinic anhydride. The beads were frequently degassed to ensure that all the pore surfaces were exposed. The beads were activated by placing them in a solution of freshly prepared 1-ethyl-3-(diethylaminopropyl)carbodiimide (EDC) in $0.2 M$ sodium phosphate, $\mathrm{pH} 4.75$, while stirring with nitrogen gas for $30 \mathrm{~min}$ at room temperature. The beads were rapidly washed with $400 \mathrm{ml}$ of ice-cold $47 \mathrm{mM}$ sodium phosphate, $\mathrm{pH}$ 7.0. A solution of avidin $(6 \mathrm{mg} / \mathrm{ml})$ in phosphate buffer was then recirculated through the beads for $24 \mathrm{~h}$. The beads were washed with $2 M$ urea in phosphate buffer, pH 7.0.
Biotin-binding sites. Biotin-binding sites on the avidin beads were determined by incubating $100 \mu \mathrm{l}$ of beads with $500 \mu \mathrm{l}$ of $0.5 \mathrm{~m} M$ biotin in $50 \mathrm{~m} M$ sodium phosphate, $\mathrm{pH} 6.0$, containing $0.9 \% \mathrm{NaCl}$, for $5 \mathrm{~min}$. Twenty-five $\mu \mathrm{l}$ of the supernatant was added to 1.025 $\mathrm{ml}$ of a HABA-avidin complex formed by combining 1 $\mathrm{ml}$ of $0.5 \mathrm{mg} / \mathrm{ml}$ avidin in $50 \mathrm{~m} M$ phosphate buffer, $\mathrm{pH}$ $6.0,0.9 \% \mathrm{NaCl}$ with $0.025 \mathrm{ml}$ of $10 \mathrm{~m} M$ HABA in 10 $\mathrm{m} M \mathrm{NaOH}$. The presence of biotin displaces HABA, which exhibits an absorption maximum at $500 \mathrm{~nm}$ when complexed with avidin. Therefore, biotin can be measured by the decrease in absorbance at $500 \mathrm{~nm}$. The biotinylated membrane vesicles were recirculated through the affinity matrix for $1 \mathrm{~h}$ at room temperature, washed with $1 \%$ polyoxyethylene-9-lauryl ether in phosphate buffer and eluted with $50 \mathrm{~m} M$ DTT in 50 $\mathrm{m} M$ phosphate buffer (Janolino and Swaisgood, 1983).

Electrophoresis/Western analysis. SDS-PAGE was performed using a Novex Xcell II Mini-Cell system. NuPAGE Bis-Tris gels with a 4 to $12 \%$ gradient were utilized and run in MES buffer. Staining and destaining of gels were performed using standard protocols. Transfer to PVDF using a Midget Multiblot Electrophoretic Transfer Unit was allowed to proceed overnight. The proteins were then probed with polyclonal CD36 antibodies to bovine MFGM CD36. Standard protocols for Western blotting were followed thereafter (Maniatis et al., 1989).

Protein concentration. The protein concentration in samples was determined using the standard bicinchoninic acid assay at $37^{\circ} \mathrm{C}$. Samples were diluted to have final concentrations between 0.1 and $1.0 \mathrm{mg} / \mathrm{ml}$ protein. BSA was used to generate standard curves.

Sulfhydryl oxidase activity. Sulfhydryl oxidase (SOX) activity was traced throughout the isolation process using glutathione in $47 \mathrm{~m} M$ sodium phosphate, $\mathrm{pH}$ 7.0, as a substrate (Janolino and Swaisgood, 1975). Disappearance of sulfhydryl groups was measured by the reaction with 5,5'-dithio-bis-(2-nitrobenzoic acid) over a 10-min period. One unit of activity was defined as $1 \mu \mathrm{mol}$ of glutathione oxidized per min.

Deglycosylation. Purified skim milk CD36 samples were treated with endoglycosidase $\mathrm{F}$ at $37^{\circ} \mathrm{C}$ for times of $0,1,2,3,4$, and $5 \mathrm{~h}$, in accordance with the method of Greenwalt et al. (1990a). The samples were then analyzed for molecular weight by SDS-PAGE.

Sequencing. After electrophoresis, samples were blotted to PVDF and stained with India ink prior to shipping. The blots were then sent to the Protein Chemistry Laboratory at Texas A\&M University for sequencing. Analysis was performed using a Hewlett Packard G1005A Protein Sequencer with an in-line HP 1090 HPLC for amino acid identification. 


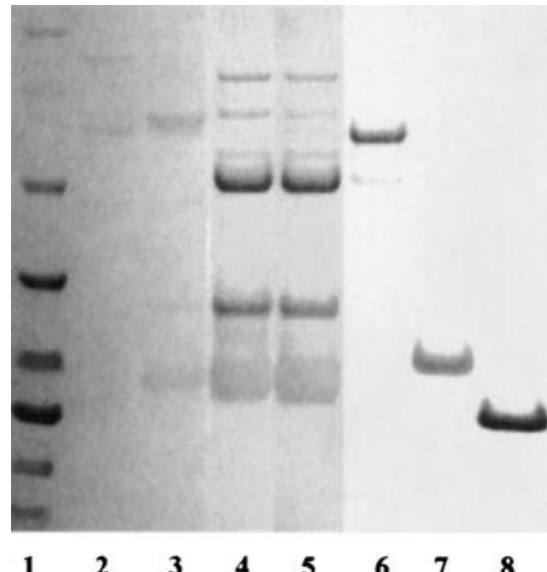

Figure 1. SDS-PAGE analysis of fractions collected from Superose-12 size-exclusion column. Lanes: 1) Molecular mass standards (150, 98, 52, 38, 20, 19, 11, 7, $3 \mathrm{kDa}$ from top); 2 through 8) fractions of increasing retention time. CD36 was the predominant protein in lane 3 . Sulfhydryl oxidase activity was observed in lanes 2 and 3.

\section{RESULTS AND DISCUSSION}

SDS-PAGE analysis of fractions collected during various stages of purification showed a significant increase in the relative concentration of 80 to $90 \mathrm{kDa}$ proteins present in the sample. The final step in the differential centrifugation method left only two or three protein bands visible in the gel (Figure 1). Similar results were observed using the ultrafiltration method (Figure 2). It should be noted that these two purification protocols were very different. The first was based on solubility, concentration-dependent precipitation, and then size-exclusion. The second was based

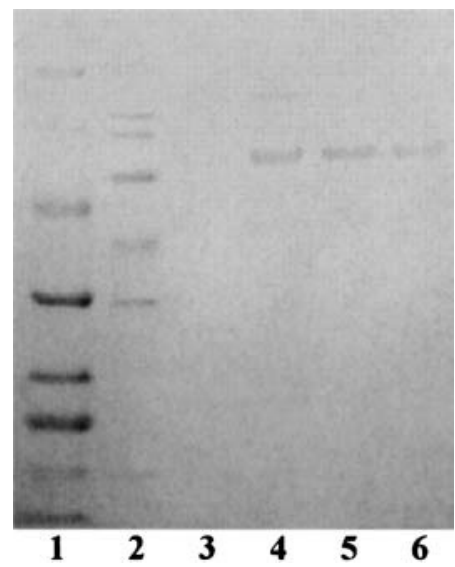

Figure 2. SDS-PAGE analysis of biotinylated proteins eluted from an avidin affinity matrix. Lanes: 1) Molecular weight standards; 2) protein sample prior to chromatography; 3 through 6) fractions eluted with increasing time. CD36 was the major protein with affinity for the matrix.

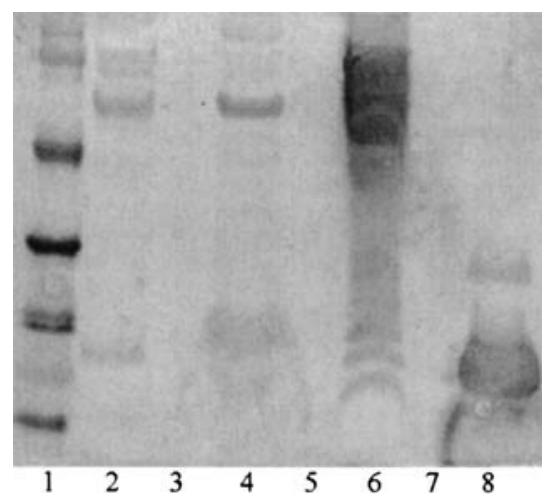

Figure 3. Western blot using antibodies to bovine MFGM CD36. Lanes: 1) molecular weight standards from top $(150,98,52,35,20$, 7); 2 and 4) purified skim milk CD36 from size-exclusion and affinity chromatography, respectively; 6) bovine MFGM CD36; 8) control consisting of streptavidin probed with anti-streptavidin antibody. This control was used to verify that nonspecific binding to the membrane did not occur. The CD36 antibody was cross-reactive among CD36 species from various sources.

on size-exclusion followed by sulfhydryl-based affinity chromatography. This would suggest that the proteins common to both completed isolations are very similar in their solubilities and size, most likely being embedded in the skim milk membrane vesicles.

One protein in particular, found in various mammalian tissues (Clare et al., 1984), was found to be present in purified fractions. SOX activity was followed

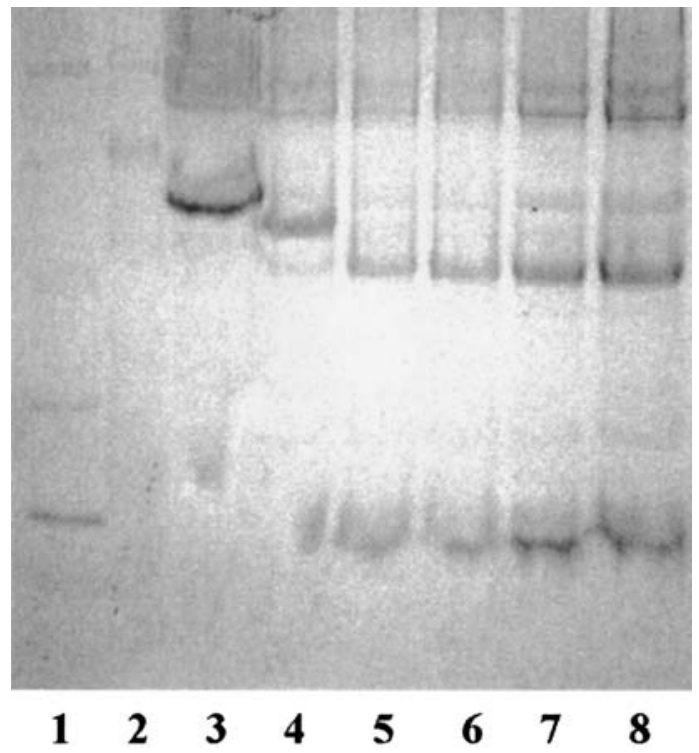

Figure 4. SDS-PAGE showing results of deglycosylation with endoglycosidase F. Lanes: 1) molecular weight standards from top (150, 98, 52, 35, 20, 7); 2) purified skim milk CD36; 3 through 8) CD36 after treatment with endoglycosidase $\mathrm{F}$ for $1,2,4,6,8$, and $12 \mathrm{~h}$, respectively. 
MGCNRNCGLI AGAVIGAVLA VFGGILMPVG DMLIEKTIKK EVVLEEGTIA FKNWVKTGTD

61

VYRQFWIFDV QNPDEVTVNS SKIKVKQRGP YTYRVRYLAK ENITQDPETN TVSFLQPNGA

121

IFEPLLSVGT EDDKFTILNL AVAAAPQLYP NTFMQGILNS FIKKSKSMF QNRTLKELLW

181

GYTDPFLNLV PYPITTTIGV FYPYNNTADG IYKVFNGKDD ISKVAIIDTY KGRKNLSYWS

241

SYCDLINGTD AASFPPLVEK TRLVGFFSSD ICRSIYAVFG AIENLKGIPV VRFVLPSFAF

301

ASPFENPDNH CFCTEKIISK NCTLYGVLDI GKCKEGKPVY ISLPHFLHGS PELAEPIEGL

361

SPNEEEHSTY LDVEPITGFT LRFAKRLQVN TGQARQKKIE ALKNLKHNYI VPILWLNETG

421

TIGDEKAEMF RNQVTGKINL LGLVEIVLLS VGVVMFIAFM ISYCAYRSKT IK

Figure 5. Entire amino acid sequence of bovine MFGM CD36. Sequences obtained from purified skim milk CD36 are shown in bold.

throughout the process and was present even in the final fractions (Table 1). It is reasonable to speculate that the proteins exist as a complex, considering that the molecular size of soluble CD36 (Greenwalt et al., 1990a; Berglund et al., 1996) was observed to be lower than those of subsequent eluants from size-exclusion 
Table 1. Presence of sulfhydryl oxidase activity.

\begin{tabular}{lcll}
\hline Fraction & $\begin{array}{l}\text { Protein } \\
\text { concentration }\end{array}$ & $\begin{array}{l}\text { Total activity } \\
\text { units } / \mathrm{ml}\end{array}$ & $\begin{array}{l}\text { Specific activity } \\
\text { units/mg }\end{array}$ \\
\hline Whey & 5.38 & 1.14 & 0.21 \\
CPG-3000 void volume & 1.07 & 0.82 & 0.77 \\
Affinity purified & 0.07 & 0.51 & 7.29 \\
Fraction C & 30 & 0.90 & 0.03 \\
Fraction E & 1.3 & 0.38 & 0.29 \\
Superose-12 eluant & 0.04 & 0.07 & 1.75 \\
\hline
\end{tabular}

${ }^{1}$ Mean of three measurements.

chromatography. Moreover, Rasmussen's group determined that free sulfhydryls are absent in CD36 (Rasmussen et al., 1998). If that is the case, then CD36 would need to be associated with SOX to bind to the sulfhydryl-reactive affinity matrix.

Because of the similar molecular size of denatured, dissociated SOX (Janolino and Swaisgood, 1975; Clare et al., 1984) and CD36 (Greenwalt et al., 1990a; Berglund et al., 1996), both in the 85 to $90 \mathrm{kDa}$ range, it was not possible to distinguish SOX bands from CD36 bands in the SDS-PAGE gels. However, to precisely identify and further characterize CD36 in the final fractions, antibodies to bovine MFGM CD36 were obtained and used for Western analysis (Figure 3). The result was positive recognition of the upper band in the gel. The apparent molecular weight of the CD36 protein was approximately $85 \mathrm{kDa}$, well within the range previously reported by other groups. However, because it had also been reported that CD36 may undergo tissue-specific glycosylation, an endoglycosidase $\mathrm{F}$ treatment was used to deglycosylate the proteins. Indeed, the CD36 present in the samples decreased in size to approximately $57 \mathrm{kDa}$ (Figure 4). This value coincided with previously reported values for CD36 from other sources.

As a final validation, sequence analysis was performed on the Western-positive protein. Three regions were sequenced, each having identity with CD36 isolated from MFGM (Figure 5).

\section{CONCLUSIONS}

Based on the results of our Western blots and sequence information, we concluded that CD36 was the protein isolated using the two purification protocols described herein. We also propose that CD36 is embedded in the skim milk membrane vesicles and possibly exists as a complex with SOX. In addition, it is evident from our deglycosylation results that tissue-specific glycosylation has occurred in the processing of the CD36, and that the skim milk and MFGM protein components of CD36 are similar, if not identical in size and primary sequence. The purification schemes presented here could be applied to further characterize the skim milk membrane protein in an attempt to develop a greater understanding of its yet unclear biological role.

\section{ACKNOWLEDGMENTS}

The authors wish to thank the Protein Chemistry Laboratory at Texas A\&M University for the sequencing results. In addition, we are grateful to T. E. Petersen and M. S. Rasmussen of the Department of Molecular Biology at the University of Aarhus, Denmark, for supplying the bovine MFGM CD36 antibodies.

\section{REFERENCES}

Berglund, L., T. E. Petersen, J. T. Rasmussen. 1996. Structural characterization of bovine CD36 from the milk fat globule membrane. Biochim. Biophys. Acta 1309:63-68.

Clare, D. A., H. R. Horton, T. J. Stabel, J. G. Lecce, and H. E. Swaisgood. 1984. Tissue distribution of mammalian sulfhydryl oxidase. Arch. Biochem. Biophys. 230:138-145.

Endenmann, G., L. W. Stanton, K. S. Madden, C. M. Bryant, R. T. White, and A. A. Protter. 1993. CD36 is a receptor for oxidized low density lipoprotein. J. Biol. Chem. 268:11811-11816.

Greenwalt, D. E. 1993. A one-step procedure for purification of bovine mammary epithelial cell CD36. Prot. Express. Purif. $4: 72-75$.

Greenwalt, D. E., and I. H. Mather. 1985. Characterization of an apically derived epithelial membrane glycoprotein from bovine milk, which is expressed in capillary endothelia in diverse tissues. J. Cell Biol. 100:397.

Greenwalt, D. E., K. W. Watt, T. Hasler, R. J. Howard, and S. Patel 1990a. Structural, functional, and antigenic differences between bovine heart endothelial CD36 and human platelet CD36. J. Biol. Chem. 265:16296-16299.

Greenwalt, D. E., K. W. Watt, O. Y. So, and N. Jiwani. 1990b. PAS IV, an integral membrane protein of mammary epithelial cells, is related to platelet and endothelial cell CD36 (GP IV). Biochem. J. 29:7054-7059.

Janolino, V. G., and H. E. Swaisgood. 1975. Isolation and characterization of sulfhydryl oxidase from bovine milk. J. Biol. Chem. 250:2532-2538.

Janolino, V. G., and H. E. Swaisgood. 1993. Purification of reactive sulfhydryl enzymes by bioselective adsorption on monomeric avidin: Purification of sulfhydryl oxidase. J. Food Biochem. 16:389-399.

Mather, I. H., C. B. Tamplin, and M. G. Irving. 1980. Separation of the proteins of bovine milk-fat-globule membrane by electrofocusing with retention of enzymatic and immunological activity. Eur. J. Biochem. 110:327-336. 
Rasmussen, J. T., L. Berglund, M. S. Rasmussen, and M. E. Petersen. 1998. Assignment of disulfide bridges in bovine CD36. Eur. J. Biochem. 257:488-494.

Sambrook, J., E. F. Fritsch, and T. Maniatis, 1989. Molecular Cloning: A Laboratory Manual. 2nd ed. Cold Spring Harbor Laboratory Press, Plainview, NY.

Sato, T., K. Furukawa, D. E. Greenwalt, and A. Kobata. 1993. Most bovine milk fat globule membrane glycoproteins contain asparagines-linked sugar chains with GalNAc beta 1-4 GlcNAc groups. J. Biochem. Tokyo 114:890-900.

Silverstein, R. L., M. Baird, S. K. Lo, and L. M. Yesner. 1992. Sense and antisense cDNA transfection of CD36 (glycoprotein IV) in melanoma cells: Role of CD36 as a thrombospondin receptor. J. Biol. Chem. 267:16607-16612.

Sliwkowski, M. B., H. E. Swaisgood, and H. R. Horton. 1982. Solubilization of sulfhydryl oxidase, a bovine skim milk membrane enzyme. J. Dairy Sci. 65:1681-1687.

Spitsberg, V. L., E. Matitashi, and R. C. Gorewit. 1995. Association and coexpression of fatty-acid-binding protein (FABP) and glycoprotein CD36 in the bovine mammary gland. Eur. J. Biochem. 230:872-878.

Tandon, N. N., R. H. Lipsky, W. H. Burgess, and G. A. Jamieson. 1989. Isolation and characterization of platelet glycoprotein IV (CD36). J. Biol. Chem. 264:7570-7575. 